This is an electronic reprint of the original article. This reprint may differ from the original in pagination and typographic detail.

Author(s): Tuomi, Margaret; Jauhojärvi-Koskelo, Camilla

Title: $\quad$ Enabling the full participation of university students with disabilities: seeking best practices for a barrier-free language centre

Year: $\quad 2015$

Version:

Please cite the original version:

Tuomi, M., \& Jauhojärvi-Koskelo, C. (2015). Enabling the full participation of university students with disabilities: seeking best practices for a barrier-free language centre. In J. Jalkanen, E. Jokinen, \& P. Taalas (Eds.), Voices of pedagogical development : expanding, enhancing and exploring higher education language learning (pp. 159-170). Research-publishing.net. https://doi.org/10.14705/rpnet.2015.000291

All material supplied via JYX is protected by copyright and other intellectual property rights, and duplication or sale of all or part of any of the repository collections is not permitted, except that material may be duplicated by you for your research use or educational purposes in electronic or print form. You must obtain permission for any other use. Electronic or print copies may not be offered, whether for sale or otherwise to anyone who is not an authorised user. 


\title{
8 Enabling the full participation of university students with disabilities: seeking best practices for a barrier-free language centre
}

\author{
Margaret Trotta Tuomi ${ }^{1}$ and Camilla Jauhojärvi-Koskelo ${ }^{2}$
}

\section{Abstract}

$\mathrm{R}$ ecent research has shown that $3.4 \%$ of university students in Finland have a diagnosed or observed illness or disability that affects their learning at the university level. The University of Jyväskylä Language Centre embarked on an organised, ongoing research and intervention project to enable appropriate teaching practices to suit the needs of all students. The process, thus far, has shown there is a need to clarify the rights and obligations of students and teachers to enable an atmosphere of mutual trust. A survey of the Language Centre teachers showed that all had taught students with disabilities during their university careers. Teachers wanted more information about disabilities, such as how to recognise disabilities if they have not been diagnosed or if students are not forthcoming with the information. Most importantly, they wanted to know the extent of their obligations as university teachers. Students also needed guidelines. They wanted to know if they could trust that their teachers would take them seriously or if disclosure of their disabilities would cause more difficulties. To date, university students and staff have been involved in the development of two websites, one for teachers and one for students, to clarify key areas for appropriate information and maximum suitability.

Keywords: barrier free language learning, higher education, identifying learning disabilities, support website

\footnotetext{
1. Language Centre, University of Jyväskylä, Finland; margaret.tuomi@jyu.fi

2. Language Centre, University of Jyväskylä, Finland; camilla.jauhojarvi-koskelo@jyu.fi
}

How to cite this chapter: Tuomi, M. T., \& Jauhojärvi-Koskelo, C. (2015). Enabling the full participation of university students with disabilities: seeking best practices for a barrier-free language centre. In J. Jalkanen, E. Jokinen, \& P. Taalas (Eds), Voices of pedagogical development - Expanding, enhancing and exploring higher education language learning (pp. 159-170). Dublin: Research-publishing.net. doi:10.14705/rpnet.2015.000291 


\section{Introduction}

When discussing the needs of elementary school starters, it comes as no surprise that a percentage of the young students require extra support due to learning or other disabilities. It may be a surprise, however, that research conducted by the Finnish Student Health Service survey in 2012 found that $3.4 \%$ of university students $^{3}$ had a diagnosed learning difficulty or illness/disability that affected their learning (Kunttu \& Pesonen 2012). The majority of the 3.4\% university students with disabilities, that is, $69.5 \%$, had dyslexia. The Finnish university students with dyslexia were asked if they had received assistance with their disability during their time in higher education; 63.4\% said that they had not. In addition to dyslexia, $8.5 \%$ had attention deficiency disorders and $4.9 \%$ had an autistic spectrum disorder, in these cases Asperger syndrome. Nearly 5\% of the students had a hearing disability and $1.2 \%$ had a visual disability. In the United Kingdom, Richardson (2009) looked at the impact disabilities had on the studies of university students. The findings showed that the only students impacted by their disabilities were those with so-called hidden disabilities such as dyslexia and Asperger syndrome.

According to the Universities Act of Finland (558/2009), factors relating to the health and functional capacity of a university applicant may not preclude their admission. Admission, however, is not enough. Full participation in university life is also required for students to complete their degrees and to arm them with the skills they need to support themselves and their families (see Tuomi, Lehtomäki \& Matonya 2015; Gidley, Hampson, Wheeler \& Bereded-Samuel 2010). The Finnish Constitution and the Non-Discrimination Act (21/2004: 2) ${ }^{4}$ requires universities to take "reasonable steps" to enable a person with disabilities to gain access to work and training. As of now, however there is no Act or Code of Practice to define just what the "reasonable" adjustments are which Finnish Higher Education Institutions (FHEI) should fulfil to realize equal access and learning for all students.

\footnotetext{
3. The data in the Student Health Survey 2012 (Kunttu \& Pesonen 2012) was collected equally from students in universities and universities of applied sciences. For this paper however, only statistics on university students were used, not on students in universities of applied sciences.

4. As amended by several acts, including No. $84 / 2009$, p.2.
} 
There are international initiatives, such as the UN Convention on the Rights of Persons with Disabilities (United Nations 2006) and the European Parliament Proposal for Directive on Accessibility of Public Sector Bodies' websites (COM (2012) 721) , that can give FHEIs more detailed directions in the near future.

As an authority supervising compliance with the terms of the Non-Discrimination Act (21/2004), the Finnish Ministry of Education and Culture has conducted surveys and reported on the accessibility of FHEIs in 2005 and 2012. The Ministry Report of 2012 shows that FHEIs have done goal-oriented work but finds that "the work is [...] still unsystematic to a degree and lacks resources [... A]t the institutional level the promotion of accessibility still has a mark of marginality" (Penttilä 2012: 6). According to the report, there seem to be challenges in studies and social participation, especially for "dyslexic students and students that have difficulties with mental health" (Penttilä 2012: 6). The ministry's recommendations for FHEIs include, among other things, work for accessibility in regard to strategic planning and the personnel's pedagogical skills and accessible use of ICT (Universities Act 558/20096).

\section{The Barrier-Free workgroup}

When university students choose their major subject, they usually gravitate towards those fields in which they have skills and talents. However, the completion of university studies also includes obligatory non-major courses, such as Finnish language composition and foreign language communication skills. These are exactly the courses that are taught by the Language Centre and that can prove to be difficult for students with hidden disabilities. Despite these difficulties, however, the students' skills acquisition in both written and oral communication in their native and foreign languages are needed for their studies and their future occupations.

5. http://eur-lex.europa.eu/procedure/EN/202205

6. http://www.finlex.fi/fi/laki/kaannokset/2009/en20090558.pdf 
In 2011, the University of Jyväskylä Language Centre embarked on an organised, ongoing action research project with its staff, composed of specialists in language teaching, communication and administration. The goal of this research is to provide a more accessible environment for students with physical, emotional or neurological disabilities to study in so that they can graduate with an academic degree and the skills needed for working life. The process, currently in its fourth year, has shown that there is a need to clarify the rights and obligations of students and teachers and to promote good practices so that it is easier for students to successfully complete their university studies.

The goal was to canvass teachers' experiences about working with the students with disabilities, to collect their best practices in barrier-free teaching and to gather their views on what and how training in barrier-free issues should be conducted. The open-ended questionnaire (see Appendix 1) focused on four main areas: (1) experiences of teachers and staff working with students with disabilities, either diagnosed or not, (2) how the teachers saw their role in teaching their students with disabilities, (3) what strategies the teachers had used in response to the needs of their students with disabilities and (4) what support the university and the Language Centre could offer to enable the teachers to teach their students with disabilities.

During this study, we have also included feedback from other experts working in various faculties and departments. Both teachers and students of special education were included in the development of a website intended for students and another for teachers only.

\section{What did we learn?}

The teachers' responses were based on their own observations, students' own reports or statements from doctors. The range of disabilities reported by the staff can be seen in Table 1. The results showed that all the Language Centre teachers had taught students with disabilities. The teachers' so-called comfort zones varied according to their experience and educational background. They 
spoke of the need for more information to appropriately train and evaluate students with physical, sensory, emotional or neurological difficulties. Since many disabilities are undiagnosed and invisible, we are, unaware of the cause, unable to know how many students do succeed without assistance and how many do not.

\subsection{What were the experiences of teachers and staff working with students with disabilities, diagnosed or not?}

When the staff was asked about what types of students with disabilities they had encountered, all responded that during their careers they had had students with a wide range of neurological, emotional, visual and physicals disabilities that affected their studies or the completion of their assignments.

Table 1. Disabilities encountered by teachers

\begin{tabular}{|l|l|}
\hline Disability & $\begin{array}{l}\text { Teachers had taught students } \\
\text { with the following disabilities } \\
\text { during their careers }(\mathbf{N}=\mathbf{4 8})\end{array}$ \\
\hline reading disabilities & 41 \\
\hline stage fright or panic disorders & 34 \\
\hline mental health problems & 29 \\
\hline hearing impairment & 26 \\
\hline visual impairment & 25 \\
\hline physical impairment & 25 \\
\hline $\begin{array}{l}\text { communication impairment } \\
\text { (e.g. stuttering) }\end{array}$ & 20 \\
\hline $\begin{array}{l}\text { attention deficiency disorders } \\
\text { (e.g. ADD, ADHD) }\end{array}$ & 19 \\
\hline $\begin{array}{l}\text { autistic spectrum disorders } \\
\text { (e.g. Asperger syndrome) }\end{array}$ & 14 \\
\hline chronic pain syndrome & 2 \\
\hline other & \\
\hline
\end{tabular}

The teachers identified the barriers which prevented students with disabilities from studying. They noticed that students needed a wide range of teaching

7. Overemotional, schizophrenia, multiple sclerosis, cerebral palsy, drug addiction, cancer 
methods and their teaching had to be modified. They gave more guidance, support materials and alternative tasks to students with disabilities. Many students needed such assistance from the teacher to collaborate with other students. Teachers could assist in enabling each student to become a full and equal member of the class despite their disabilities.

\subsection{How did the teachers see their role when teaching students with disabilities?}

Teachers provided special arrangements, when needed, to better suit the students' needs and to give them support and encouragement. They wanted to refer students with disabilities to professionals in student health services. Teachers were concerned that they were being asked to function in a way that was beyond their capacity. They were trained as adult educators in language, communication and administration of staff. They had not been trained to recognise neurological disabilities. How could they identify students with undiagnosed disabilities when the students themselves were unaware of their own disabilities? Was it the teacher's duty to bring up the subject that students' difficulties in studying might be caused by disabilities? Some mentioned that such a discussion was both outside their range of expertise and their job mandate.

\subsection{What strategies did the teachers use in response to the needs of their students with disabilities?}

The teachers had tailored their methods of teaching and student evaluation. They had provided extra materials, advice, tips and instructions. Different types of feedback and self-study tasks were implemented. One teacher even mentioned that she had learned sign language to enable good communication with students with hearing impairment. Several teachers mentioned that they had had many private discussions with the students, paid attention to the teaching arrangements, booked more accessible classrooms, provided a computer for tasks, took interpreters into account, sent materials in advance and gave teaching materials in a variety of formats. 


\subsection{What support did the teachers need when teaching students with disabilities?}

Across the board, the teachers requested training. They requested information on what professionals they could refer their students to so that their students could learn study strategies, on how to discuss with students about their disabilities and on how to identify students with undiagnosed disabilities. In addition, training was requested on how to take the whole class into consideration when one or more students in the class had disabilities that disrupted other students. The teachers wanted to know what their rights and obligations as teachers were, that is, what was included and not included in their role as teachers of students with disabilities. Training sessions where teachers discuss where the rights and obligations of teachers lie in the realisation of a barrier-free Language Centre. For example, a traffic light could symbolically be used to differentiate what tasks were clearly within their obligations as teachers to fulfill, that is, a "green light", what was definitely not within their obligations to fulfill, a "red light", and finally, what areas are unclear, a "yellow light" (Eerola 2014). This type of training can help to clarify the role of teachers in various situations. Most of all the teachers wanted to know where they could turn to when support was needed. The teachers requested written instructions about barrier-free teaching and basic information about various learning barriers. Some, especially part-time teachers, asked about remuneration, wondering if they would be paid for the time spent in the adaptation of materials for students with disabilities.

\section{What has been done so far?}

As requested by the Language Centre staff, a series of training sessions on a range of topics was offered by a number of professionals on:

- different types of disabilities and how teachers could better help students who have such disabilities by the principal lecturer in special education at the Jyväskylä University of Applied Sciences; 
- the rights and obligations of teachers and students by the university planner responsible for students with disabilities;

- what teachers should do if a crisis situation should occur in their classes by the Head of Safety and Security at the University of Jyväskylä;

- the training of a network of university staff members in each department to promote a barrier-free learning environment by two leaders of the Student Life programme, in the context of a meeting with the Language Centre director and the Barrier-Free workgroup;

- how teachers can guide their students to a professional who can assist them in the development of learning strategies by the psychologist of the University Health Services;

- assisting the staff to identify the perimeter of their roles as teachers, the content of their job descriptions and the setting of boundaries in their roles as teachers.

Additionally, both students and teachers have collaborated on the development of two websites, one for Language Centre staff and one for students. The website for staff includes valuable information on a variety of disabilities and training links. The site for students has been prepared, in a style that is suitable for all, to assist students who may have questions on how to proceed to study in collaboration with their teacher if they believe that they themselves may have a disability. Most of all, both websites clearly state the rights and obligations of university teachers and students.

\section{Barrier-free website for language teachers: fear is NOT part of a teacher's work}

The materials provided on the website reinforce professional development training. The teachers were concerned that they were being asked to fulfil a task 
for which they had no training. The website emphasises that teachers are not being asked to act as psychologists, doctors or special education teachers. Rather, it presents basic information included on learning disabilities which affect adults, such as ADHD, autistic spectrum disorder, panic attacks and social anxiety. Case studies on each of these disabilities are also included. The teachers are instructed not to condone physical or emotional abuse from their students, no matter what the cause. The most important advice is, of course, to seek assistance from one's colleagues, university staff and health services. What is stressed is that there is no need for teachers to feel alone, a work environment based on consultation and collaboration being an important step forward (see Tuomi 2004).

\section{Barrier-free website for students ${ }^{8}$}

The website for students provides instructions concerning students' rights and obligations. Encouraging statements from the Language Centre teachers are also included, pointing out, for example, that all students can complete courses with the same level of difficulty but in different ways, such flexibility making it fair for all. Questions from students with various learning disabilities, such as dyslexia, are answered and guidance is provided. There is also information on students' well-being, performance anxiety and self-direction, among other things. University students are adults responsible for their own studies, development and decisions. Data are now being collected from students with disabilities on their experiences in Language Centre studies.

\section{Conclusions}

When one considers that $3.4 \%$ of university students have disabilities which affect their studies (see Kunttu \& Pesonen 2012), it comes as no surprise that all of the University Language Centre staff had taught students with disabilities. What is a surprise, however, is that so little is taught in the pedagogical studies

8. https://kielikeskus.jyu.fi/esteeton (in Finnish) 
of teachers of adults in higher education and how little it is discussed in the university environment. Perhaps university students, being adults, are mistakenly assumed to have overcome any disabilities, as if they were a matter of concern for elementary school children only. This assumption is obviously false.

The education of each and every individual is necessary for the continued progress of society. We must not allow barriers to stand in their way. The Barrier-Free Language Centre is just a start, but it is a good start, based on research and the practical experiences of teachers and students, with disabilities or not. Furthermore, in the university milieu, students are not the only ones with disabilities; recent research has examined tertiary teachers with dyslexia, their "professional identity negotiation" (Burns 2015: 16) and their success with their different palette of talents. More research in this and other areas is needed. It is only through openness, research and experience that this process can and will move forward.

\section{Acknowledgments}

The Barrier Free Language Centre working group would like to thank University of Jyväskylä Planning Coordinator Hannu Puupponen for his support and comments in the production of this article.

\section{References}

Burns, E. 2015. Tertiary teachers with dyslexia as narrators of their professional life and identity. Jyväskylä: University of Jyväskylä.

Eerola, S. 2014. Haastavat ohjaustilanteet ja puheeksi ottaminen [Introducing difficult subjects and other challenging situations when guiding Ssudents]. From a training session given by Eerola for the Language Centre of the University of Jyväskylä.

Gidley, J. M., Hampson, G. P., Wheeler, L. \& Bereded-Samuel, E. 2010. From access to success: an integrated approach to quality higher education informed by social inclusion theory and practice. Higher Education Policy, 23 (1), 123-147. doi:10.1057/hep.2009.24 
Kunttu, K. \& Pesonen, T. 2012. Student health survey 2012: a national survey among Finnish university students. Helsinki: Yliopilaiden terveydenhoitosäätiö.

Non-Discrimination Act (21/2004). Retrieved from https://www.finlex.fi/fi/laki/kaannokset/2004/ en20040021.pdf

Penttilä, J. 2012. Hitaasti, mutta varmasti? Saavutettavuuden edistyminen yliopistoissa ja ammattikorkeakouluissa 2000-luvulla [Slowly but surely? Progress in the accessibility of university and polytechnic education in the 2000s]. Helsinki: Opetus- ja kulttuuriministeriön julkaisuja. Retrieved from http://www.minedu.fi/export/sites/default/ OPM/Julkaisut/2012/liitteet/okm10.pdf?lang=fi

Richardson, J. T. E. 2009. The academic attainment of students with disabilities in UK higher education. Studies in Higher Education, 34 (2), 123-137. doi:10.1080/03075070802596996

Tuomi, M. T. 2004. Planning teachers' professional development for global education. Journal of Intercultural Education, 15 (3), 295-306.

Tuomi, M. T., Lehtomäki, E. \& Matonya, M. 2015. As capable as other students: Tanzanian women with disabilities in higher education. International Journal of Disability, Development and Education, 62 (2), 202-214. doi:10.1080/1034912X.2014.998178

United Nations. 2006. Convention on the rights of persons with disabilities. New York: United Nations.

\section{Appendix 1}

Barrier-Free Language Centre Learning Environment

Questionnaire for the staff of Jyväskylä University Language Centre

Respondent

1) What types of students with disabilities have you encountered in your work? How many of your students have had disabilities which affected their studies or assignments? Circle the appropriate choices using the following scale:

$0=$ none

$1=$ very few, a few students during the past few years

$2=$ few, a few during the past year 
$3=$ more than five students during the past year

$4=$ more than ten students in the past year

$5=$ more than fifteen students in the past year
a) Visual disability ${ }^{9}$
012345
b) Hearing disability
012345
c) Physical disability
012345
d) Communication disability, e.g. stuttering
012345
e) Reading disabilities
012345
f) Stage fright or panic disorders
012345
g) Autistic spectrum disorders, e.g. Asperger Syndrome 012345
h) Attention deficiency disorders, e.g. ADD, ADHD 012345
i) Mental health problems
012345
j) Chronic pain syndrome
012345
k) Other, describe

2) What, in your opinion, is your role as a teacher/facilitator when teaching students with disabilities?

3) With those students who have disabilities:

a) What types of barriers have you noticed which prevent your students from studying?

b) How have you responded to these barriers? (For example, different materials, discussion with student/class, developed a new teaching method - what kind?)

c) What type of support or training would you have needed? How could the University Language Centre support you? What other types of support could you use from the university?

9. The original questionnaire $(a, b, c)$ used the word "impaired" rather than disability. 


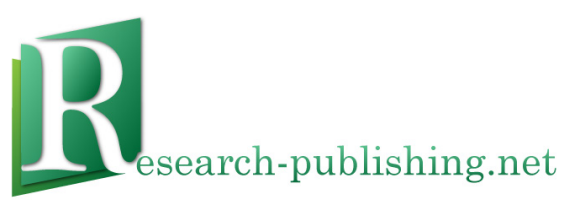

Published by Research-publishing.net, not-for-profit association Dublin, Ireland; Voillans, France, info@research-publishing.net

(C) 2015 by Research-publishing.net (collective work)

Each author retains their own copyright

Voices of pedagogical development - Expanding, enhancing and exploring higher education language learning Edited by Juha Jalkanen, Elina Jokinen, \& Peppi Taalas

Rights: All articles in this collection are published under the Attribution-NonCommercial -NoDerivatives 4.0 International (CC BY-NC-ND 4.0) licence. Under this licence, the contents are freely available online (as PDF files) for anybody to read, download, copy, and redistribute provided that the author(s), editorial team, and publisher are properly cited. Commercial use and derivative works are, however, not permitted.

\section{()ㅛ $\Theta \Theta$}

Disclaimer: Research-publishing.net does not take any responsibility for the content of the pages written by the authors of this book. The authors have recognised that the work described was not published before, or that it is not under consideration for publication elsewhere. While the information in this book are believed to be true and accurate on the date of its going to press, neither the editorial team, nor the publisher can accept any legal responsibility for any errors or omissions that may be made. The publisher makes no warranty, expressed or implied, with respect to the material contained herein. While Research-publishing.net is committed to publishing works of integrity, the words are the authors' alone.

Trademark notice: Product or corporate names may be trademarks or registered trademarks, and are used only for identification and explanation without intent to infringe.

Copyrighted material: Every effort has been made by the editorial team to trace copyright holders and to obtain their permission for the use of copyrighted material in this book. In the event of errors or omissions, please notify the publisher of any corrections that will need to be incorporated in future editions of this book.

Typeset by Research-publishing.net

Cover design by (C) Antti Myöhänen

ISBN13: 978-1-908416-25-4 (Paperback - Print on demand, black and white)

Print on demand technology is a high-quality, innovative and ecological printing method, with which the book is never 'out of stock' or 'out of print'.

ISBN13: 978-1-908416-26-1 (Ebook, PDF, colour)

ISBN13: 978-1-908416-27-8 (Ebook, EPUB, colour)

Legal deposit, Ireland: The National Library of Ireland, The Library of Trinity College, The Library of the University of Limerick, The Library of Dublin City University, The Library of NUI Cork, The Library of NUI Maynooth, The Library of University College Dublin, The Library of NUI Galway.

Legal deposit, United Kingdom: The British Library.

British Library Cataloguing-in-Publication Data.

A cataloguing record for this book is available from the British Library.

Legal deposit, France: Bibliothèque Nationale de France - Dépôt légal: septembre 2015. 